\title{
A Five-year Retrospective Review of Infants with Erb-Duchenne's Palsy at a Teaching Hospital in North Trinidad
}

\author{
A Jaggat, M Mencia, T Ali, V Stewart
}

\begin{abstract}
Birth injuries are devastating to parents and carers alike. They carry the possibility of residual loss of function to the infant and thus the potential for litigation. The aim of this study was to determine the incidence of Erb-Duchenne's palsy and the identification of any contributing factors. A retrospective review over a five-year period, 2005-2009, was performed and an incidence of 0.94 per 1000 live births was noted. An association between both macrosomia and shoulder dystocia and the development of ErbDuchenne palsy in the newborn was noted. The authors recommended the use of partograms and improved note documentation in the management of labour.
\end{abstract}

Keywords: Erb-Duchenne's palsy, macrosomia, North Trinidad, shoulder dystocia

\section{Revisión Retrospectiva Quinquenal de Infantes con la Parálisis de Erb Duchenne en un Hospital Docente en el Norte De Trinidad}

\author{
A Jaggat, M Mencia, T Ali, V Stewart
}

\begin{abstract}
RESUMEN
Las lesiones de nacimiento resultan devastadoras tanto para los padres como para los cuidadores. Ellos conllevan la posibilidad de pérdida residual de función para el infante y por ende la potencialidad de litigios. El objetivo de este estudio fue determinar la incidencia de la parálisis de Erb Duchenne y la identificación de cualquiera de los factores contribuyentes. Se llevó a cabo una revisión retrospectiva por un periodo de cinco años, 2005-2009, y se observó una incidencia de 0.94 por 1000 nacimientos vivos. Se observó una asociación entre macrosomía y distocia del hombro, por una parte, y el desarrollo de la parálisis de Erb Duchenne, por otra parte, en el recién nacido. Los autores recomendaron usar partogramas y mejorar la documentación de las notas clínicas durante el trabajo de parto.
\end{abstract}

Palabras claves: Parálisis de Erb Duchenne, macrosomía, Trinidad Norte, distocia del hombro

West Indian Med J 2013; 62 (1): 45

\section{INTRODUCTION}

Birth injuries could be hypoxic or mechanical. Hypoxic injury included conditions such as birth asphyxia whereas mechanical injuries encompassed both skeletal and nerve injuries

Brachial plexus injury (BPI) has a prevalence of between 0.5 and 4.4/1000 live births (1). It is commonly believed to be attributed to extensive lateral traction during difficult neck delivery (2).

Brachial plexus palsy affects nerve roots C5-6 in ErbDuchenne palsy in nearly $80 \%$ of cases whereas C8-T1,

From: The University of the West Indies Office, Bungalow 5, Port-of-Spain General Hospital, Trinidad and Tobago.

Correspondence: Dr A Jaggat, The University of the West Indies Office, Bungalow 5, Port-of-Spain General Hospital, No 1 Charlotte Street, Port-of-Spain, Trinidad and Tobago. E-mail: anillajaggat@gmail.com
Klumpke's palsy, occurs less frequent (3). Erb's palsy occurs in 0.9 to 2.6 per 1000 live births (4). Eighty per cent will resolve by three to six months of age, while $1 \%$ to $5 \%$ persists one year after delivery (5). Known risk factors are macrosomia and shoulder dystocia (4).

One five-year review of birth trauma published in 1996 demonstrated that occurrence of birth injuries was associated with prolonged gestation, epidural anaesthesia, prolonged second stage of labour, oxytocin use, forceps delivery, shoulder dystocia, fetal macrosomia, previous obstetric history of macrosomia, low APGAR scores, meconium in labour and neonatal hyperbilirubinaemia (2).

This paper aims to look at one aspect of birth injuries, Erb-Duchenne palsy, its incidence and contributing factors. 


\section{SUBJECTS AND METHODS}

All infants sustaining Erb-Duchenne palsy during birth were identified via the neonatal clinic at Port-of-Spain General Hospital (POSGH). The notes of the infants were reviewed and the mothers' hospital numbers were identified. The mothers' notes were then reviewed, looking at known risk factors for birth trauma (2) such as ethnicity, parity, antenatal care, history of diabetes, history of macrosomia, presentation of the fetus, prolonged gestation, oxytocin use, duration of labour, presence of meconium, mode of delivery, birthweight of infants and APGAR scores.

Ethical approval was gained from both the University of the West Indies, St Augustine and North West Regional Health Authority (NWRHA) Ethics Committee.

\section{RESULTS}

During the five-year period 2005 to 2009 , there were 16 infants diagnosed with Erb-Duchenne palsy. The number of live births in this same period was 16 997, giving an incidence of 0.94 in 1000 live births.

Out of the 16 infants identified as having Erb-Duchenne palsy, 15 of the maternal notes were found and analysed. The mean maternal age was 30.2 years, with a median value of 31 years (range 19-43).

Calculation of the body mass index was not possible due to incomplete data recording in the medical notes.

All patients had antenatal care, ten at the POSGH, four at the local health centre with one having private care only. Three were primigravidae with two mothers carrying their first pregnancy to term having undergone multiple miscarriages. Of the 15 mothers, three had a history of diabetes mellitus in the current pregnancy. Two of these mothers displayed signs of clinical diabetes mellitus. Only the mother with gestational diabetes had a history of macrosomic babies.

All pregnancies were singleton, cephalic/vertex undergoing vaginal deliveries; none required forceps or ventouse deliveries. Four patients were given an oxytocin infusion delivery during the first stage of labour with only one requiring induction of labour with prostaglandin. Seven infants were born with meconium stained liquor.

The mean infant birthweight was $4.368 \mathrm{~kg}$ with a median value of $4.37 \mathrm{~kg}$ (range 3.51-5.38). Eleven infants were classified as macrosomic, ie birthweights greater than $4 \mathrm{~kg}$, nine infants had birthweights of $4 \mathrm{~kg}$ to $5 \mathrm{~kg}$; two weighed over $5 \mathrm{~kg}$. Nine of the deliveries were documented as difficult shoulder delivery/shoulder dystocia with eight being macrosomic babies. Twelve of the infants had APGAR scores that were less than seven.

\section{DISCUSSION}

Birth injuries are devastating to parents and carers alike. It carries the possibility of residual loss of function to the infant and thus the potential for litigation.

The incidence of Erb-Duchenne palsy at this hospital is 0.94 per 1000 live births which is in keeping with previous studies (4). In a similar five-year study by Perlow et al, there were 17 infants with BPI among 19370 live births (2).

On reviewing the maternal demographics, the only outstanding variable was ethnicity where the majority were of African descent. This may, however, reflect the ethnicity of the antenatal population at this particular hospital rather than a contributing factor to Erb-Duchenne palsy. The two main contributing factors to Erb-Duchenne palsy in this study group were fetal macrosomia and shoulder dystocia.

Weizsaecker et al cited fetal macrosomia as the main cause of BPI because large fetal size lends itself to dysfunctional labour (1). In their paper, dysfunctional labour was defined as prolonged latent phase, protracted dilation or descent, arrest of dilation or descent, prolonged deceleration phase and failure of descent. We were unable to corroborate these findings as partograms were not in use during this period and inadequate medical documentation made interpretation of the course of labour impossible.

Seventy-three per cent of the infants who sustained ErbDuchenne palsy were macrosomic, with shoulder dystocia occurring in $60 \%$ of the deliveries. Of the cases complicated by shoulder dystocia, $89 \%$ of the infants were macrosomic. Shoulder dystocia lends itself to BPI for two reasons: (i) in utero where the anterior shoulder may become impacted against the symphysis pubis and (ii) during delivery where the infant's neck could become over-extended (5).

Doumouchtsis and Arulkumaran cited a 4-40\% incidence of BPI following shoulder dystocia with a significant proportion secondary to in utero injury (6). In another paper by the same authors, it was estimated that endogenous forces, $i e$ forces associated with labour, were 4-9 times greater than any traction force used ie the force exerted by the person doing the delivery (3). This evidence further lends to the inability to predict shoulder dystocia and thus prevent its occurrence.

All these patients had spontaneous vaginal delivery which asks the question: is Caesarean section protective against these injuries? Firstly, BPI can occur during elective Caesarean section. Secondly, even though the Royal College of Obstetricians and Gynaecologists (7) recommends that elective Caesarean section be considered in diabetic women with a fetal weight $(\mathrm{EFW})>4.5 \mathrm{~kg}$ and in non-diabetic women with an EFW greater than $5 \mathrm{~kg}, 443$ Caesarean sections would need to be performed to prevent one permanent BPI in diabetic women with an EFW of $4.5 \mathrm{~kg}$ and 3695 Caesarean sections in the non-diabetic population (6). Thirdly, Caesarean section carries inherent anaesthetic and surgical risks to the mother.

Ultrasound can be utilized in predicting fetal weight prior to delivery. Weeks et al stated that ultrasonography and labour induction for patients at risk for fetal macrosomia should be discouraged (8). The authors think that there is a role for ultrasonography in suspected macrosomia even though estimation may sometimes be inaccurate, since this allows for counselling of the patients in the antenatal period as per mode of delivery. Estimation of fetal size would also alert the clinicians of the possibility of shoulder dystocia occurring during 
labour and allow for optimal management of dysfunctional labour.

\section{CONCLUSION}

In this study, the main factors associated with Erb-Duchenne palsy were fetal macrosomia and shoulder dystocia. Unlike other studies, fetal macrosomia contributed to shoulder dystocia in the majority of cases. Diabetes was not significant in causing macrosomia as only three mothers were diabetic.

\section{Recommendations}

The routine use of partograms would allow for an accurate record of the progress in labour so that any delay or deviation from normal may be detected quickly and treated, thereby decreasing the possibility of BPI in an at-risk fetus.

\section{ACKNOWLEDGEMENTS}

Special thanks to medical interns Rachel Thomas-George, Anushka Saroop and Renee Haywood.

\section{REFERENCES}

1. Weizsaecker K, Deaver JE, Cohen WR. Labour characteristics and neonatal Erb-Duchenne palsy. BJOG 2007; 114: 1003-9.

2. Perlow JH, Wigton T, Hart J, Strassner HT, Nageotte MP, Wolk BM. Birth trauma. A five-year review of incidence associated perinatal factors. J Reprod Med 1996; 41: 754-60.

3. Doumouchtsis SK, Arulkumaran S. Are all brachial plexus injuries caused by shoulder dystocia? Obstet Gynecol Surv 2009; 64: 615-23.

4. Chater M, Camfield P, Camfield C. Who is to blame and what will happen? Paediatr Child Health 2004; 9: 556-60.

5. Gherman RB, Ouzounian JG, Miller DA, Kwok L, Murphy Goodwin T. Spontaneous vaginal delivery: a risk factor for Erb-Duchenne palsy? Am J Ostet Gynecol 1998; 178: 423-7.

6. Doumouchtsis SK, Arulkumaran S. Is it possible to reduce obstetrical brachial plexus palsy by optimal management of shoulder dystocia? Ann N Y Acad Sci 2010; 1205: 135-43.

7, Royal College of Obstetricians and Gynaecologists. Shoulder dystocia. Green Top Guidelines No 42. [published March 2012]. London: RCOG. Available from: http://www.rcog.org.uk/womens-health/clinical-guid ance/shoulder-dystocia-green-top-42

8. Weeks JW, Pitman T, Spinnato JA $2^{\text {nd }}$. Fetal macrosomia: does antenatal prediction affect delivery route and birth outcome? J Obstet Gynecol 1995; 173: 1215-9. 